\title{
ANALYSIS OF NITRATE CONCENTRATIONS USING NONLINEAR TIME SERIES MODELS
}

\author{
PETER VALENT ${ }^{1)}$, NICHOLAS J. K. HOWDEN ${ }^{2)}$, JÁN SZOLGAY'1), MAGDA KOMORNÍKOVÁ ${ }^{3)}$ \\ ${ }^{1)}$ Department of Land and Water Resources Management, Faculty of Civil Engineering, Slovak University of Technology, \\ Slovakia; Mailto: peter_valent@stuba.sk \\ ${ }^{2)}$ Department of Civil Engineering, Faculty of Engineering, University of Bristol, United Kingdom. \\ ${ }^{3)}$ Department of Mathematics and Descriptive Geometry, Faculty of Civil Engineering, Slovak University of Technology, Slovakia.
}

This study examines two long-term time series of nitrate-nitrogen concentrations from the River Ouse and Stour situated in the Eastern England. The time series of monthly averages were decomposed into trend, seasonal and cyclical components and residuals to create a simple additive model. Residuals were then modelled by linear time series models represented by models of the ARMA (autoregressive moving average) class and nonlinear time series models with multiple regimes represented by SETAR (self-exciting threshold autoregressive) and MSW (Markov switching) models. The analysis showed that, based on the minimal value of residual sum of squares (RSS) of one-step ahead forecast in both datasets, SETAR and MSW models described the time series better than models ARMA. However, the relative improvement of SETAR models against ARMA models was low ranging between $1 \%$ and $4 \%$ with the exception of the three-regime model for the River Stour where the improvement was $48.9 \%$. In comparison, the relative improvement of MSW models was between $44.6 \%$ and 52.5 for two-regime and from $60.4 \%$ to $75 \%$ for three-regime models. However, the visual assessment of models plotted against original datasets showed that despite a high value of RSS, some ARMA models could describe the analyzed time series better than AR (autoregressive), MA (moving average) and SETAR models with lower values of RSS. In both datasets MSW models provided a very good visual fit describing most of the extreme values. The results of this work could be used as a base for construction of other time series models used to describe or predict nitratenitrogen concentrations.

KEY WORDS: Nitrate Time Series, ARMA Models, SETAR Models, MSW Models.

Peter Valent, Nicholas J. K. Howden, Ján Szolgay, Magda Komorníková: ANALÝZA KONCENTRÁCIÍ DUSIČNANOV POMOCOU NELINEÁRNYCH MODELOV ČASOVÝCH RADOV. J. Hydrol. Hydromech., 59, 2011, 3; 37 lit., 9 obr., 2 tab.

Štúdia sa zaoberá analýzou dlhých časových radov koncentrácií dusičnanového dusíka v rieke Ouse a Stour vo Východnom Anglicku. Časové rady priemerných mesačných koncentrácií dusičnanov boli rozložené na trendovú, sezónnu a cyklickú zložku a reziduá pripočítané k sebe a tvoriace jednoduchý aditívny model. Reziduá boli d’alej modelované zložitejšími lineárnymi modelmi reprezentovanými modelmi triedy ARMA a nelineárnymi viacrežimovými modelmi SETAR a MSW. Výsledky analýzy ukázali, že na základe minimálnej hodnoty sumy štvorcov reziduí (SSR) jednokrokovej predpovede, v oboch prípadoch SETAR aj MSW modely opísali časové rady lepšie ako modely triedy ARMA. Vo väčšine prípadov relatívne zlepšenie modelov SETAR oproti jednoduchým AR(1) modelom bolo malé v rozmedzí od 1 do $4 \%$ $\mathrm{s}$ výnimkou trojrežimového modelu pre rieku Stour, kde to bolo až 48,9 \%. Naopak, relatívne zlepšenie modelov MSW oproti AR(1) modelom bolo v rozmedzí 44,6 až 52,5\% pre dvojrežimové a 60,4 až $75 \%$ pre trojrežimové modely. Vizuálne posúdenie jednotlivých modelov však ukázalo, že napriek vysokým hodnotám SSR, niektoré ARMA modely dokázali lepšie opísat' dané časové rady ako modely AR, MA a SETAR s nižšími hodnotami SSR. V oboch prípadoch MSW modely dokázali dostatočne dobre opísat' aj extrémne hodnoty oboch časových radov. Výsledky práce môžu byt' použité pri tvorbe iných opisných alebo predpovedných modelov koncentrácie dusičnanového dusíka vo vodách.

KLUUCČOVÉ SLOVÁ: časové rady dusičnanov, modely ARMA, modely SETAR, modely MSW. 


\section{Intoduction}

Nitrates are one of the most important pollutants causing eutrophication of surface and subsurface and underground water bodies. This became a subject of interest in many developed countries. Higher concentrations of nitrate in water bodies can have serious implications on the environment such as: overgrowth of phytoplankton, decrease of dissolved oxygen, reduction of water transparency leading to the loss of various plant and animal species a thus to the degradation of the whole aquatic environment and biological diversity (Seehauser et al., 1997).

European Community directives characterize nitrates as soluble substances, which main source in water bodies are runoff from agricultural land and municipal waste waters from sewage treatment works (EEA, 2005; Wrc, 2004). The lack of information about the negative impact of nitrates on water quality led to a higher usage of nitrogen fertilizers in agriculture in the second half of the $20^{\text {th }}$ century, causing that at the end of the century many European rivers and lakes were seriously affected with this kind of pollution. This critical situation led to the establishment of new legislative and regulatory measures aiming the reduction of nitrate pollution in all water bodies. Most important of them are the Directive 91/676/EEC concerning the protection of water against pollution from agriculture, the Directive 91/271/EEC concerning pollution from municipal waste water or the Directive 2000/60/EC also called water framework directive.

The introduction of these directives encouraged the responsibles to introduce several measures in order to reduce nitrate concentrations in European water bodies. A simple tool to assess the successfulness of these measures can be time series analysis of measured nitrate concentrations. Some information obtained by the time series analysis such as whether the system generating the nitrate concentrations is linear or nonlinear or how many regimes it comprises of can lead to the identification of a particular nitrate generating mechanism and thus to better understanding of a system as a whole.

World literature contains several studies dealing with the time series analysis of nitrate concentrations. As an example Casey and Clarke (1979) in their study were dealing with the statistical analysis of nitrate concentrations in River Frome in the Southern England. Changes in stream nitrate concentrations caused by the land management practic- es were studied by Worrall et al. (2003), where the time series of nitrate concentrations was decomposed into trend and annual cycle before modeled by AR models. Schoch et al. (2009) used time series models to develop a model describing nitrate concentrations downstream of the reservoir as a function of the concentrations entering the reservoir. This model was then used to provide a 1month forecast for downstream water quality. Another example of using time series analysis in the prediction of nitrate concentrations is a study of Stronge et al. (1997) examining the causes of the year-to-year variation in river $\mathrm{NO}_{3}$ in Northern Ireland rivers. The temporal and spatial analysis of nitrate time series and the source apportionment modeling can be found in the studies of Howden and Burt (2008) and Howden et al. (2009). Other authors are Worrall and Burt (1999) who used autoregressive models to estimate nitrate concentrations for water management applications. Trend analysis and seasonality in time series is very well described in studies of Burt and Worall (2009), Worall and Burt (1998) or Betton et al. (1991).

In Slovakia this topic is studied mainly by Pekarova focusing on the time series analysis of nitrates and other water quality elements. In her studies she uses classical linear models of class ARMA, but also models with long memory such as ARIMA (autoregressive integrated moving average) and SARIMA (seasonal ARIMA) models to describe observed time series and predict nitrate concentrations in the future. Some of her studies are Pekarova (1995, 1996, 2005, 2009).

In the last decades a lot of new techniques in time series analysis have been introduced. Some of them are nonlinear time series models with multiple regimes. In this paper we have analyzed two time series of monthly averages of nitrate-nitrogen $\left(\mathrm{NO}_{3}-\mathrm{N}\right)$ concentrations in British Rivers Ouse and Stour (see Figs. 1 and 2) with linear and nonlinear models with multiple regimes. The main objective of this paper was then to compare the performance of traditional linear models of class ARMA (autoregressive moving average) and compare them with nonlinear models with multiple regimes represented by models SETAR (self-exciting threshold autoregressive) and MSW (Markov switching). As pointed out by Amendola (2003), even though nonlinear time series models have led to good fitting performances, it doesn't mean that they can guarantee an equally good forecasting performance (Chatfield, 2001). Nowadays new approaches such as 


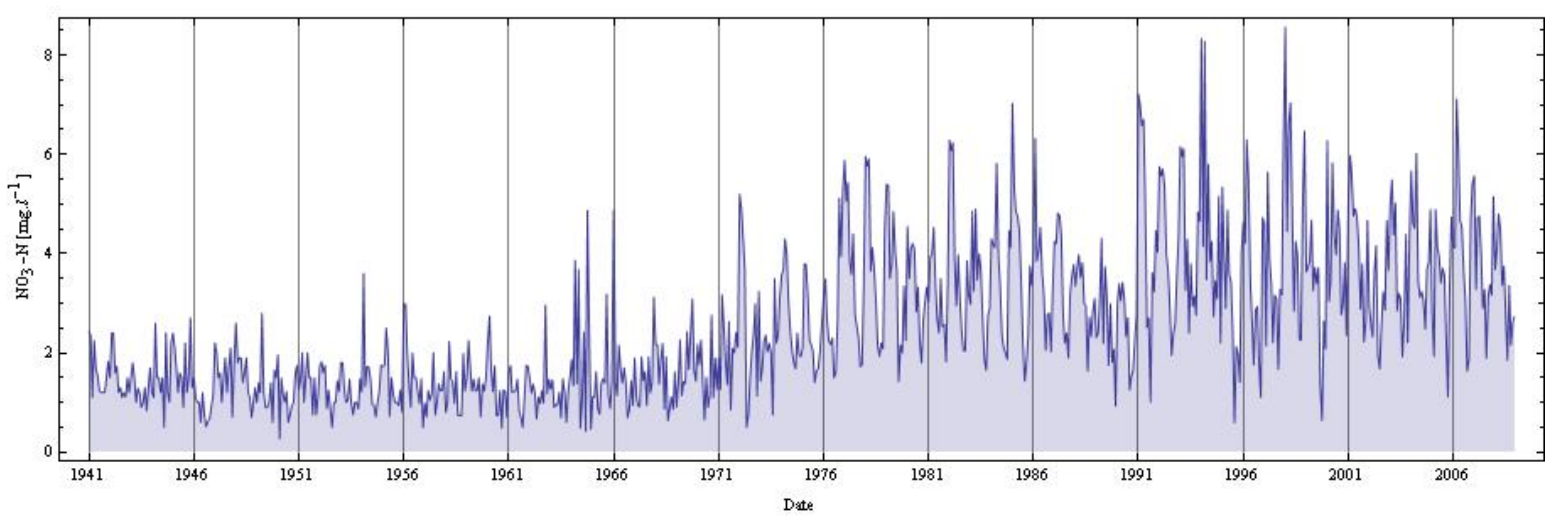

Fig. 1. Monthly averages of nitrate concentrations of River Ouse at Acomb Landing between 1941 and 2008.

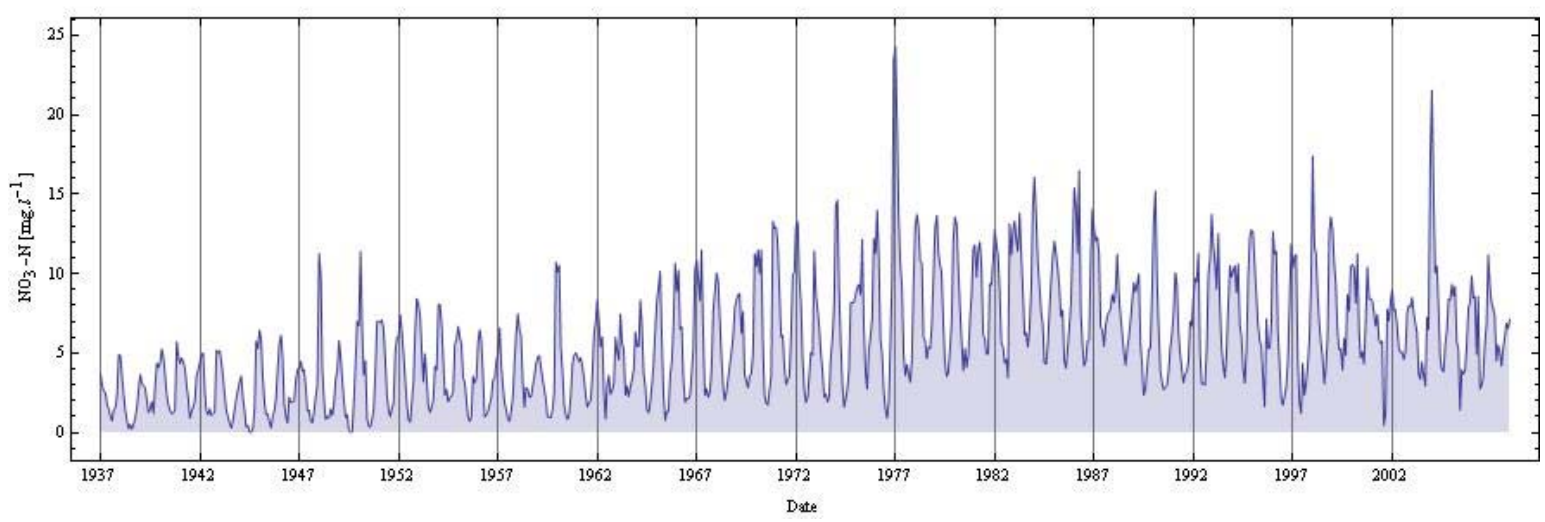

Fig. 2. Monthly averages of nitrate concentrations of River Stour at Langham between 1937 and 2007.

artificial neural networks (ANN) are being tried to compensate for this problem (e.g. Firat and Gungor, 2010; Yurdusev and Firat, 2009).

\section{Data description}

In this study we have analysed two long-term time series of monthly averages of nitrate-nitrogen $\left(\mathrm{NO}_{3}-\mathrm{N}\right)$ concentrations from British rivers Ouse (at Acomb Landing) and Stour (at Langham Bridge). Data from both datasets were provided by the Environment Agency as point measures with a sampling frequency from 0 to 5 measurements per month. Since some months were without any measurements, missing data had to be filled from other monitoring sited situated within $1.8 \mathrm{~km}$ from the original site. The rest of the missing values were calculated according to the following procedure. In the first step we have transformed the concentrations in each year into values between 0 and 1 . Then we have calculated means of these values for all months to obtain a characteristic pattern of ni- trate-nitrogen concentrations in a year. In the next step we have fitted a cosine curve to these data and filled the gaps with the values calculated from the curve equation. At the end we have transformed the filled values ranging from 0 to 1 into concentrations. The time series from River Ouse spans a period between January 1941 and December 2008 and contains 816 values (see Fig. 1). The second time series from River Stour includes data from January 1937 to December 2007 and contains 852 values (see Fig. 2).

\section{Methodology}

Because linear models of class ARMA can be used only to model stationary time series (with constant mean and variance), it was necessary to maintain stationarity of the observed datasets. This was done by decomposing the original time series into particular systematic components comprising of trend, seasonal, cyclical and residual components, where the last one was further used for mod- 
eling. Individual systematic components were added to each other to create an additive model which can be written as:

$Y_{t}=T_{t}+S_{t}+C_{t}+R_{t}$

where $T$ is trend, $S$ - seasonal, $C$ - cyclical and $R$ is residual component.

\subsection{Trend component}

Trend can be characterized as a long-term change in the mean value of time series. In order to remove the trend component from the original time series we have used a regression of the following functions: linear, quadratic, exponential, logistic and Gompertz, where the last two were S-shaped functions in this form:

$$
\begin{aligned}
& T_{\log }=\frac{a}{1+b e^{-c t}} \\
& T_{\text {Gomp }}=a+b e^{-c e^{-d t}}
\end{aligned}
$$

where $a, b, c, d$ are function parameters. Function representing the trend component was then selected based on the minimal value of residual sum of squares (RSS), which can be calculated from the following formula:

$$
R S S=\sum_{t=1}^{n}\left(x_{t}-\tilde{x}_{t}\right)^{2}
$$

where $\tilde{x}_{t}$ is modelled value.

\subsection{Seasonal component}

Seasonal component describes periodic changes in a time series, where the period is usually equal to a standard length of time. Seasonal component can also be characterized as a correlation dependence between $i^{\text {th }}$ and $(i+k)^{\text {th }}$ element of a time series, where $k$ is a lag. The period of a time series was estimated from correlogram using an autocorrelation function (Chatfield, 1989; Box and Jenkins, 1976). The seasonal component was removed from detrended time series using a harmonic function with a 12-month period, which can be written as:
$S_{t}=a+b \cos \left(\frac{2 \pi}{12} t\right)+c \sin \left(\frac{2 \pi}{12} t\right)$

where $a, b, c$ are function parameters.

\subsection{Cyclical component}

Some time series can in addition to a period of seasonal component contain another "hidden" periods which don't correspond to calendar units. Periods of the cyclical component were estimated by the methods of spectral analysis (e.g. Chatfield, 1989; Jenkins, 1968; Hamilton, 1994), where those statistically significant were estimated by the Fisher's test of periodicity (Fisher, 1929). The cyclical component was modelled by a harmonic function and removed from the detrended and deseasonalized time series. The harmonic function we have used can be described as:

$$
\begin{aligned}
& C_{t}=\alpha_{1}+\alpha_{2} \cos \left(\frac{2 \pi}{P_{1}} t\right)+\alpha_{3} \sin \left(\frac{2 \pi}{P_{1}} t\right)+ \\
& +\cdots \alpha_{i+1} \cos \left(\frac{2 \pi}{P_{i}} t\right)+\alpha_{i+2} \sin \left(\frac{2 \pi}{P_{i}} t\right)
\end{aligned}
$$

where $\alpha_{\{1,2, \ldots, \text { i+2\} }}$ are function parameters and a $P_{\{1 \text {, }}$ $2, \ldots$, i\} are statistically significant periods.

After removing all the systematic components from the original time series we have used the Kwiatkowski-Philips-Schmidt-Shin (KPSS) test to test the residuals for the stationarity (Kwiatkowski et al., 1992). Time series of residuals was then modelled with linear and nonlinear models.

\section{Linear models of class ARMA}

Linear models of class ARMA are represented by models AR, MA and their combination models ARMA described in the work of Box and Jenkins (1970), who developed a methodology to estimate their parameters. Particular models were estimated by a Hannan-Rissanen procedure (Hannan and Rissanen, 1982), where the best models are chosen based on the minimal value of AIC (Akaike information criterion) and BIC (Bayesian information criterion). Particular AR, MA and ARMA models can be written as:

$$
\begin{aligned}
& x_{t}=\varphi_{1} x_{t-1}+\cdots+\varphi_{p} x_{t-p}+z_{t} \\
& x_{t}=z_{t}+\theta_{1} z_{t-1}+\cdots+\theta_{q} z_{t-q}
\end{aligned}
$$


$x_{t}=\varphi_{1} x_{t-1}+\cdots+\varphi_{p} x_{t-p}+z_{t}+$

$+\theta_{1} z_{t-1}+\cdots+\theta_{q} z_{t-q}$

where $p$ and $q$ are model orders, $\varphi_{\{1,2, \ldots, p\}}$ and $\theta_{\{1,2 \text {, }}$ $\ldots, q\}$ - their parameters and $z_{t}$ are independent and identically distributed (i.i.d.) random variables with mean equal 0 and constant variance $\sigma^{2} z_{t} \sim \mathrm{N}\left(0, \sigma^{2}\right)$. For details on linear ARMA models see, e. g. (Box and Jenkins, 1970). After estimating the best models of the ARMA class we have used a particular model to perform a one-step ahead forecast, predicting each value of a modelled time series (except of the first several values which were used as initial conditions for a particular model). This enabled us to compare the forecasted and modelled data (in our case residuals) by calculating their RSS and so assess the forecasting ability of each model.

\section{Nonlinear models SETAR and MSW}

The basic idea of the nonlinear time series models is that certain properties of the time series, such as its mean, variance and autocorrelation are different in different regimes of the modelled process. Models SETAR and MSW belong to a group of nonlinear regime-switching models. In this work we restrict our attention to models assuming that each model comprises of several regimes described with a simple AR model. SETAR models are a special case of TAR (threshold autoregressive) models, where a regime used to calculate value in time $t$ is given by a previous value $y_{t-d}$ ( $d$ is a lag) and a threshold value $c$. In the case of two-regime SETAR model the first regime is used when $y_{t-d} \leq c$ and second if $y_{t-d}>c$. Three-regime SETAR model can be written as:

$$
x_{t}=\left\{\begin{array}{cl}
\varphi_{0}^{(1)}+\varphi_{1}^{(1)} x_{t-1}+\cdots+\varphi_{p}^{(1)} x_{t-p}+z_{t}^{(1)} & \text { if } x_{t-d} \leq c_{1} \\
\varphi_{0}^{(2)}+\varphi_{1}^{(2)} x_{t-1}+\cdots+\varphi_{p}^{(2)} x_{t-p}+z_{t}^{(2)} & \text { if } c_{1}<x_{t-d} \leq c_{2} \\
\varphi_{0}^{(3)}+\varphi_{1}^{(3)} x_{t-1}+\cdots+\varphi_{p}^{(3)} x_{t-p}+z_{t}^{(3)} & \text { if } c_{2}<x_{t-d}
\end{array}\right.
$$

where $\varphi_{i}^{j}(i \in\{1,2, \ldots, p\}$ and $\mathrm{j} \in\{1,2, \ldots, k\})$ are parameters of AR models in particular regimes, $c_{\{1}$, $2, \ldots, k-1\}$ are threshold values, $d-$ lag and $z_{t}$ is an i.i.d. where $\mathrm{z}_{\mathrm{t}} \sim \mathrm{N}\left(0, \sigma^{2}\right)$. SETAR models are extensively described in e.g. Hamilton, 1994; Tong, 1990; Tsay, 1989.

MSW models are primarily associated with Hamilton (1989, 1994). The structure of MSW models is identical to SETAR models. The only difference is the way of switching from one regime to another, when in the case of MSW model the regime used to calculate value in time $t$ is given by an unobserved variable $s$, acquiring only positive integer values $\{1,2, \ldots, k\}$, where $k$ is the number of regimes. Since the $\left\{s_{t}\right\}$ variables are driven by a Markov chain process they occur with transition probabilities

$$
P\left(s_{t}=j \mid s_{t-1}=i\right)=p_{i j}
$$

where $j$ and $i$ are some particular integer values of $s_{t}$. Variable $p_{i j}$ is then a probability that regime $i$ will be followed by regime $j$. Three-regime MSW model can be written as:

$$
x_{t}=\left\{\begin{array}{cc}
\varphi_{0}^{(1)}+\varphi_{1}^{(1)} x_{t-1}+\cdots+\varphi_{p}^{(1)} x_{t-p}+z_{t}^{(1)} & \text { when } s_{t}=1 \\
\varphi_{0}^{(2)}+\varphi_{1}^{(2)} x_{t-1}+\cdots+\varphi_{p}^{(2)} x_{t-p}+z_{t}^{(2)} & \text { when } s_{t}=2 \\
\varphi_{0}^{(3)}+\varphi_{1}^{(3)} x_{t-1}+\cdots+\varphi_{p}^{(3)} x_{t-p}+z_{t}^{(3)} & \text { when } s_{t}=3
\end{array}\right.
$$


where $\varphi_{i}^{j}(\mathrm{i} \in\{1,2, \ldots, p\}$ and $\mathrm{j} \in\{1,2, \ldots, k\})$ are parameters of AR models in particular regimes and $z_{t}$ is an i.i.d. where $z_{t} \sim N\left(0, \sigma^{2}\right)$. Further information about the MSW models can be obtained from (e.g. Brooks, 2009; Franses and van Dijk, 2003).

In this study only two and three-regime models were used. In the case of SETAR models we were able only to estimate the best two and three-regime model while in the case of MSW models we could also estimate particular models with different lags. This was due to the limitations of the applications we have used. Similarly as in the case of models of the ARMA class we have used the estimated MSW and SETAR models to compute a one-step ahead forecast enabling us to calculate RSS for each model.

\section{Results}

First analysed time series was a time series of monthly averages of nitrate-nitrogen $\left(\mathrm{NO}_{3}-\mathrm{N}\right)$ concentrations in River Ouse. Trend analysis showed that the best fit was provided by the Gompertz curve giving the lowest value of RSS. For estimat- ing the seasonal component we have used a 12month period estimated from the correlogram (Fig. $3 a)$. By removing the seasonal component from the detrended time series we have managed to reduce the RSS from 940.9 to 711.5. After removing the trend and seasonal components from the original time series we have plotted another correlogram from which we can see that not all correlation has been removed (Fig. 3b). This residual correlation has been removed by removing cyclical component from the data. The periods used for the harmonic function were estimated using the methods of spectral analysis. Statistically significant periods were estimated by Fisher's test of periodicity returning the following periods: $12.12,11.82$ and 81.6 months. From these, only first two periods were used since the last one couldn't be explained. Even though the periods 12.12 and 11.82 are very similar to the period of seasonal component and their use is questionable we have decided to use them in the model of cyclical component in order to demonstrate this new approach in the analysis of nitrate concentrations.
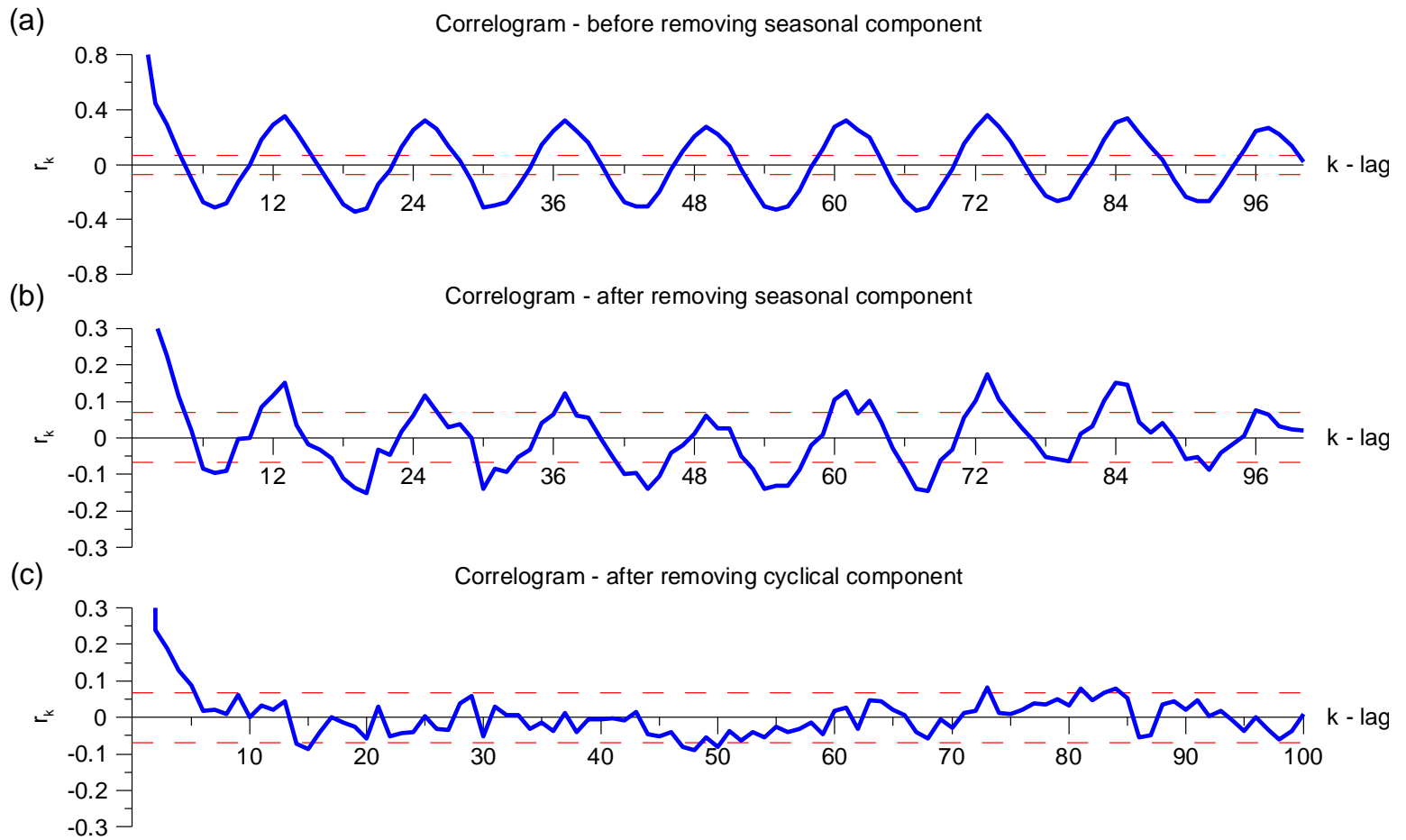

Fig. 3. Correlograms showing the correlation between data at different lags. Red dashed lines represent $95 \%$ confidence level. Within these lines the correlation is statistically equal 0 .

By removing all the systematic components from the original time series we got a new stationary time series. In the next step we have used the resid- uals for linear and nonlinear modelling. We have used both linear and nonlinear models to create a one-step ahead forecast calculated for $x_{\{i, i+1, \ldots, n\}}$, 
where $i$ is determined by the model order and $n$ is the length of a time series. In the next step we have calculated RSS for each of these predictions. The results of the analysis are shown in Tab. 1 and depicted in Fig. 4. In order to better assess the goodness of a particular model we have calculated empirical cumulative distribution functions (ECDF) showing the differences in the modelled and simulated data (see Fig. 5). Fig. 5 shows that all linear models and both SETAR models were not able to satisfactory follow especially the upper and bottom tails of the ECDF calculated for modelled data (red dashed line). However, in the case of both MSW models both modelled and simulated ECDF curves are overlapping showing a good fit.
The second analysed time series was a time series of monthly averages of nitrate-nitrogen $\left(\mathrm{NO}_{3}\right.$ $\mathrm{N})$ concentrations from River Stour. As in the case of the previous time series the best function describing the trend component was Gompertz curve. The periods used to fit the model of cyclical component are 11.8 and 12.2 months. By removing all systematic components from the original time series we have managed to reduce RSS from 8372.5 to 3060.8 and obtain a stationary time series of residuals, which was further used in the linear and nonlinear modelling. The results of the analysis are listed in Tab. 2 and the best models are depicted in Fig. 7.
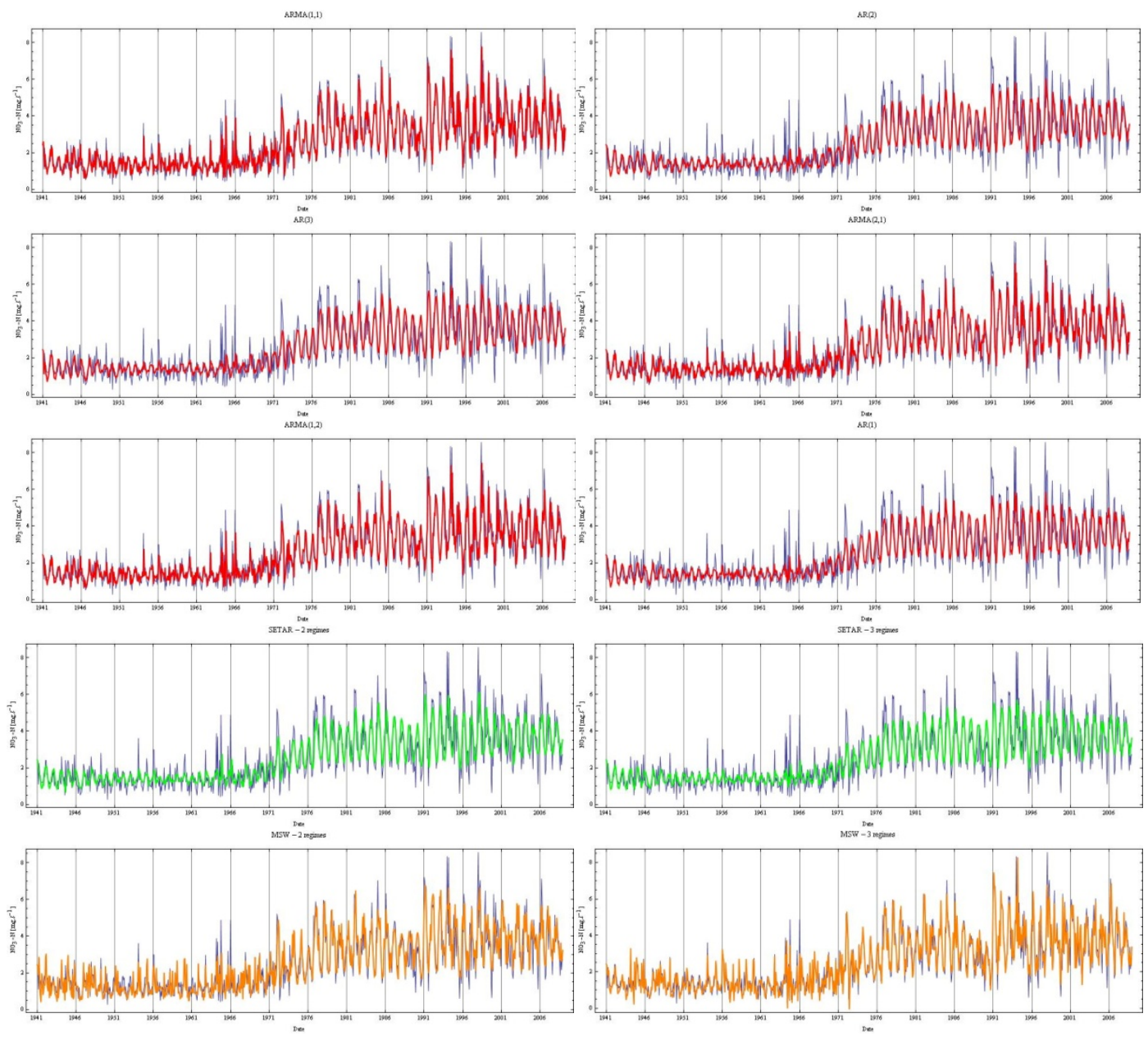

Fig. 4. Estimated ARMA (red), SETAR (green) and MSW (orange) models together with all systematic components (trend, seasonal and cyclical) plotted against original time series (blue).

\section{Discussion}

The overall pattern of time plots (Figs. 1 and 2) of both analysed time series indicates that the stable state of nitrate-nitrogen concentrations observed in the early years of both datasets has radically changed in the mid of 1970s in the case of River Ouse and between 1960 and 1970 in the case of River Stour. This radical increase in nitratenitrogen concentrations can be assigned to the in- 
a)

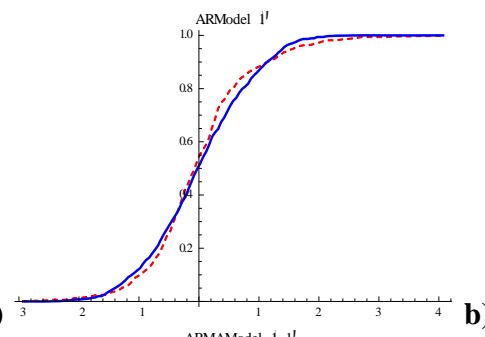

d)

g)

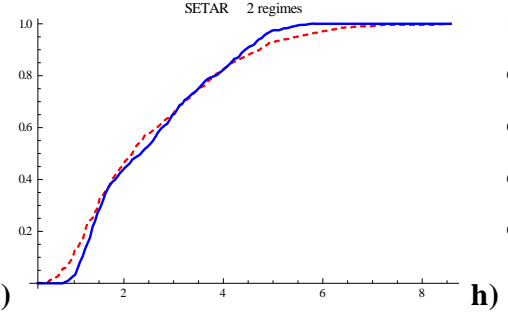

e)
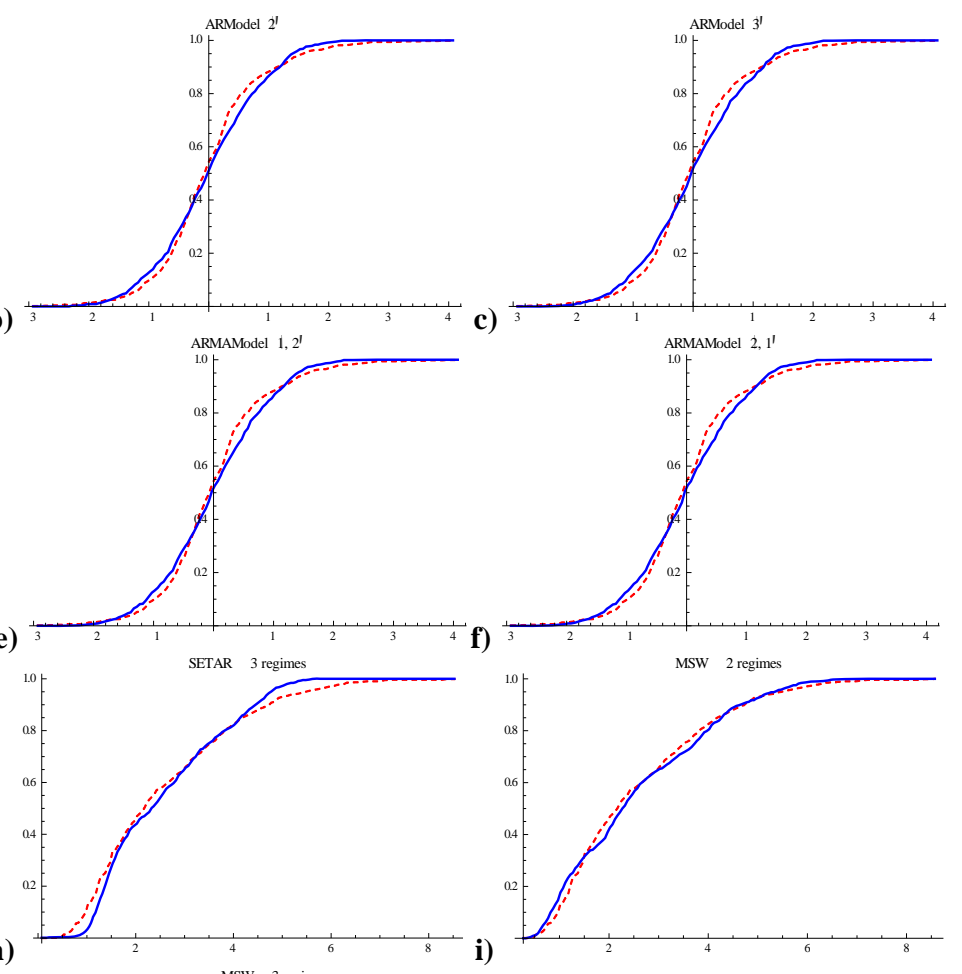

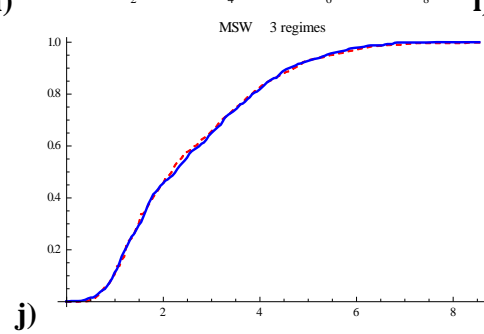

Fig. 5. Empirical cumulative distribution functions calculated for selected models of the River Ouse time series. Red dashed line represents CDF function for modelled data and blue line for model. The particular plots represent following models: a) AR(1), b) $\operatorname{AR}(2)$, c) $\operatorname{AR}(3)$, d) $\operatorname{ARMA}(1,1)$, e) $\operatorname{ARMA}(1,2)$, f) $\operatorname{ARMA}(2,1)$, g) SETAR -2 regimes, h) SETAR - 3 regimes, i) MSW - 2 regimes and $\mathrm{j}$ ) MSW -3 regimes.

tensification of farming practices within the catchment that included: ploughing of grassland, application of nitrogen fertilizers, introduction of new crops with high soil erosion potential and higher stocking densities on pastures (Burt and Arkell, 1987). In both datasets the level of nitrate-nitrogen concentration after this rapid increase seems to get into a new equilibrium. However, since the beginning of 1990s the concentrations in River Stour seem to decline again. It is not possible to be certain about what is the origin of this behaviour, but some of the possible answers are that a big part of the nitrate, stored in the catchment, has already been washed into water bodies or that the decrease has been caused by the implementation of new legislative.
The rapid change in the nitrate-nitrogen concentrations in both rivers and theirs subsequent return into another equilibrium may also be observed in the trend analysis, where S-shaped Gompertz curve provided the best fit for both time series. It is also worth to mention that despite good descriptive characteristics, curve fitting technique doesn't have to be ideal for analysing large datasets since if the dataset contains several places where the values of time series rises and falls it is then impossible to meaningfully fit a simple function such as those we have used in this study.

By fitting a harmonic function with a 12-month period a substantial part of the variation from both datasets have been removed. However, from the correlograms depicted in Figs. 3 and 6 it is obvious that not all periodicity could be removed. The rea- 
(a) Correlogram - before removing seasonal component

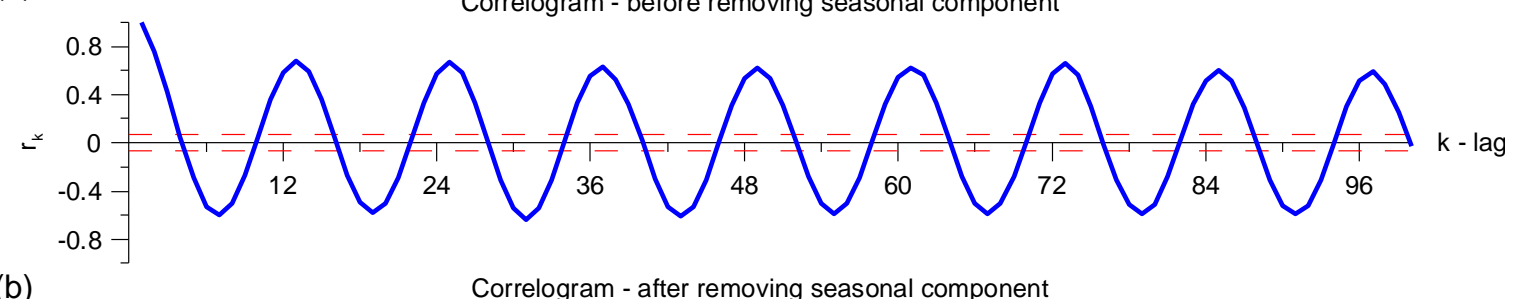

(b)

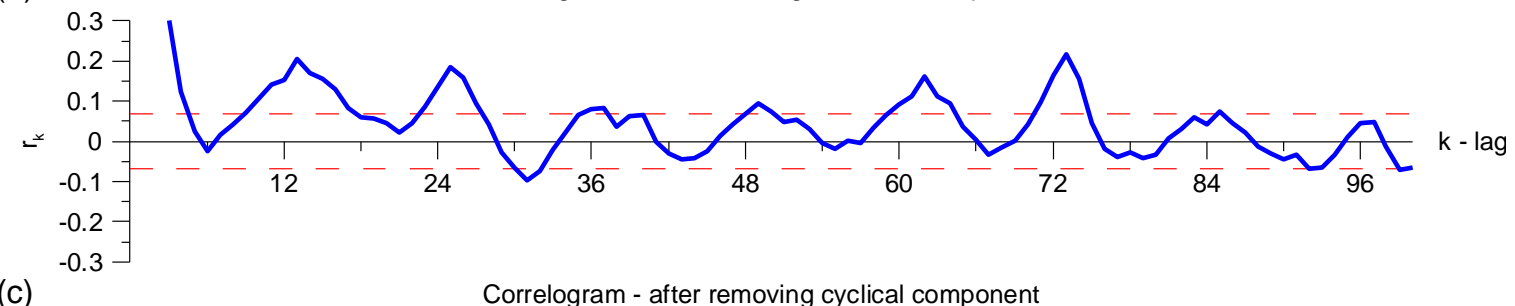

(c)

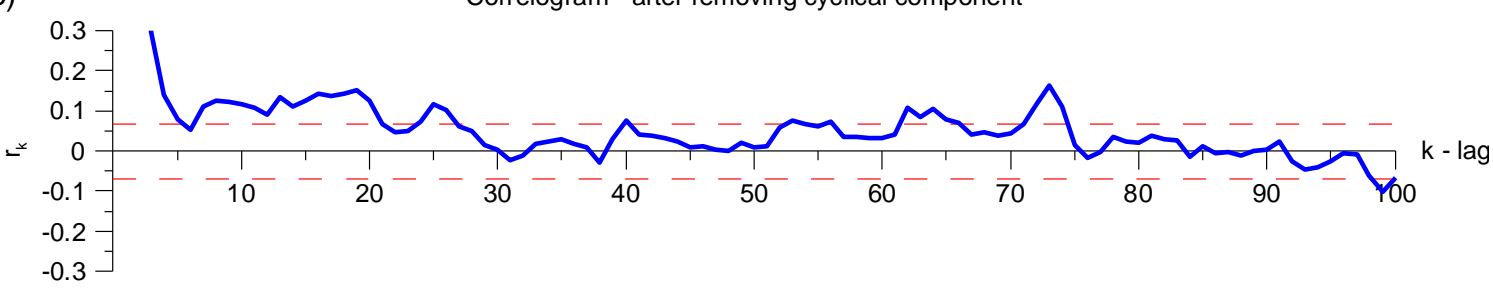

Fig. 6. Correlograms showing the correlation between data at different lags. Red dashed lines represent $95 \%$ confidence level. Within these lines the correlation is statistically equal 0.

son of this could be the response of the catchment to various human or natural impulses (e.g. periodical changes in agricultural production or fertilizer application).

This additional periodicity has been removed by fitting another harmonic curve with periods obtained from spectral analysis. Statistically significant periods estimated by Fisher's test of periodicity are $12.12,11.82$ and 81.6 for the River Ouse and $11.8,426,852,12.2,284,71,8,65.5,8.5,106.5$ and 12.5 for the River Stour. Since some of these periods cannot be explained by catchment behaviour only these periods were used to create the model of cyclical component: 12.12, 11.82 for the River Ouse and 11.8 and 12.2 for the River Stour. Even though all selected periods of cyclical component are very close to the period of seasonal component (12 months) we have decided to include them into the model since we wanted to demonstrate this new approach in the analysis of nitrate time series. The correlograms depicted in Figs. 3c) and $6 \mathrm{c}$ ) shows that using this method all observable periodicity was removed. The removing of cyclical component also substantially decreased the RSS of both datasets as described in Tabs. 1 and 2 .

After the trend, seasonal and cyclical components were subtracted from the original time series the residuals were further modelled by models of class ARMA. After the estimation of the best ARMA class models we have done a one-step ahead forecast and calculated RSS for every model (see Tabs. 1 and 2). Based on the value of RSS the best models in both datasets were simple AR models with $\operatorname{AR}(2)$ being the best model for both datasets. Moreover in both datasets more complex ARMA models had much higher values of RSS. In the case of the River Ouse the application of models AR$\operatorname{MA}(1,1), \operatorname{ARMA}(2,1)$ and $\operatorname{ARMA}(1,2)$ on the residuals increased the value of RSS and thus worsened the model performance. However, the visual assessment of models plotted against the original time series (Figs. 4 and 7) shows that despite the lower values of RSS, AR models struggle to catch extreme values. In contrary ARMA models with much higher values of RSS seem to have no problems with following most of the extreme values and thus describe both datasets much better. According to the visual assessment of model performance the best models for both datasets would be $\operatorname{ARMA}(1$, 1) for River Ouse and $\operatorname{ARMA}(2,1)$ and $\operatorname{ARMA}(1$, 3) for River Stour. All these models also have the highest values of RSS. A detailed look at the plots shows that ARMA models despite their similar pattern to original (modelled) time series they are shifted by 1 or more time steps (see Fig. 9). 

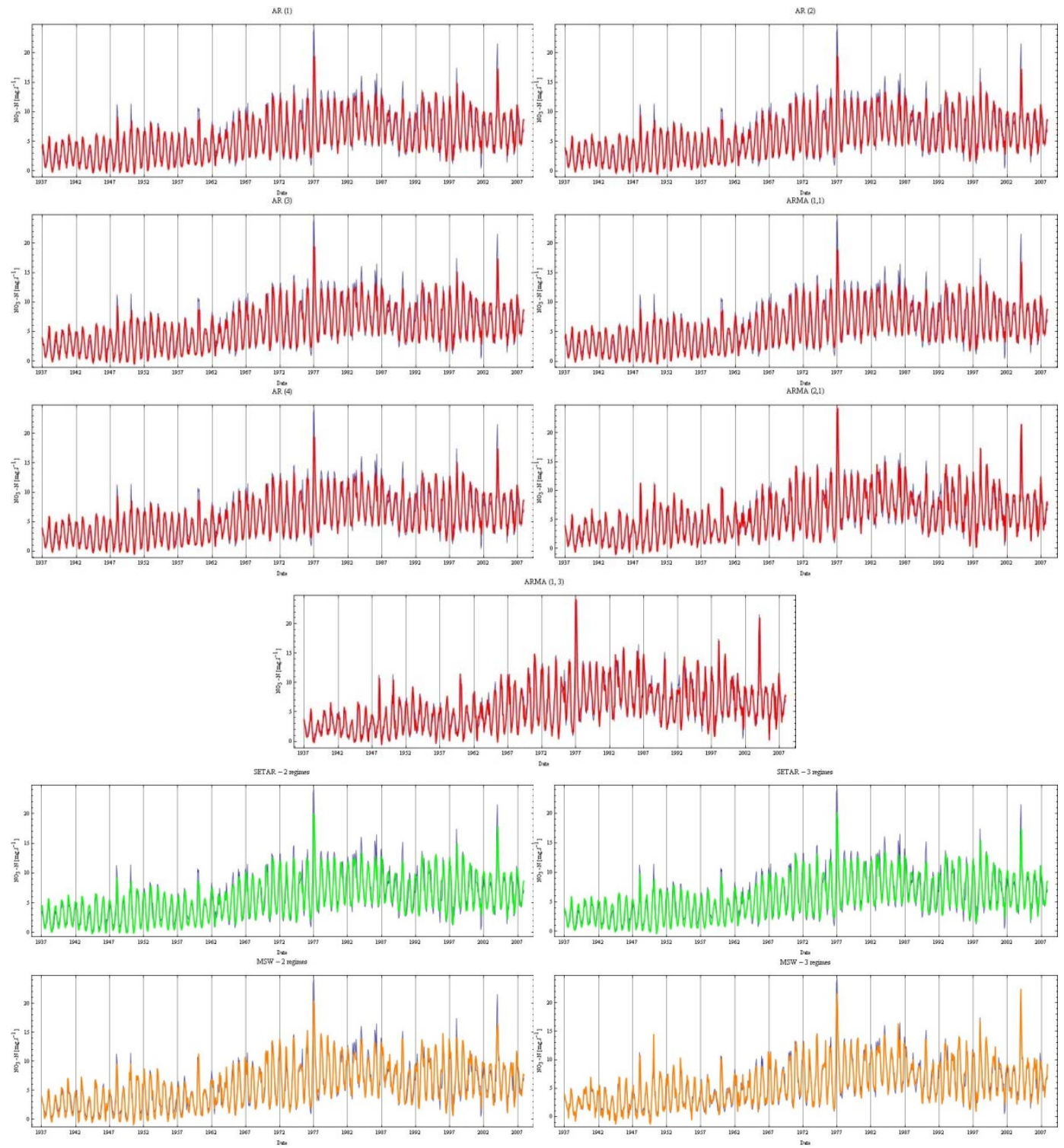

Fig. 7. Estimated ARMA (red), SETAR (green) and MSW (orange) models together with all systematic components (trend, seasonal and cyclical) plotted against original time series (blue).

Estimated two and three-regime SETAR models improved the basic model of systematic components in both time series except of River Ouse where the three-regime SETAR model gives higher value of RSS than in the best AR(2) model. The relative improvement of SETAR models against simple AR(1) model is relatively low ranging between $1 \%$ and $4 \%$ except of three-regime model for River Stour with a relative improvement is $48.9 \%$. However, the visual assessment of the models plotted against original time series (Figs. 4 and 7) shows that all estimated models had problems to describe extreme values. The origin of this problem could be the same as in the case of ARMA models, where models with good visual fit had the highest values of RSS.

In both datasets the use of ECDF (Figs. 5 and 8) showed that all models of the ARMA class and SETAR models were not able to match the upper and lower tail of the ECDF calculated for observed data. In the case of both MSW models we have managed to achieve a very good fit of observed and simulated ECDF curves, which means that MSW models didn't have problems to describe even extreme values.

As expected from the previous studies (Lenčuchová, 2009), MSW models provided the best fit with the lowest values of RSS. In the case of River Ouse the best two and three-regime MSW models 
T a b 1 e 1. Particular components of the time series analysis. Relative improvement comparing to AR(1) model is calculated as $\left.\left(\mathrm{RSS}_{\mathrm{AR}(1)}-\mathrm{RSS}\right) / \mathrm{RSS}_{\mathrm{AR}(1)}\right)$.

\begin{tabular}{|c|c|c|c|}
\hline \multicolumn{2}{|c|}{ Component } & RSS & Relative improvement comparing to AR(1) [\%] \\
\hline \multirow{2}{*}{\multicolumn{2}{|c|}{$\begin{array}{l}\text { Original data } \\
\text { Systematic components }\end{array}$}} & - & - \\
\hline & & & \\
\hline \multicolumn{2}{|c|}{ Trend } & 940.9 & - \\
\hline \multicolumn{2}{|c|}{ Seasonal } & 711.5 & - \\
\hline \multicolumn{2}{|c|}{ Cyclical } & 630.2 & - \\
\hline \multicolumn{4}{|c|}{ ARMA class } \\
\hline \multicolumn{2}{|c|}{$\mathrm{AR}(1)$} & 599.3 & $0.0 \%$ \\
\hline \multicolumn{2}{|r|}{$\operatorname{ARMA}(1,1)$} & 731.8 & $-22.1 \%$ \\
\hline \multicolumn{2}{|r|}{$\operatorname{AR}(2)$} & 581.3 & $3.0 \%$ \\
\hline \multirow{2}{*}{\multicolumn{2}{|c|}{$\begin{array}{l}\operatorname{AR}(3) \\
\operatorname{ARMA}(2,1)\end{array}$}} & 584.7 & $2.4 \%$ \\
\hline & & 659.2 & $-10.0 \%$ \\
\hline \multicolumn{2}{|r|}{$\operatorname{ARMA}(1,2)$} & 690.9 & $-15.3 \%$ \\
\hline \multicolumn{4}{|l|}{ SETAR } \\
\hline \multicolumn{2}{|r|}{2 regimes } & 575.4 & $4.0 \%$ \\
\hline \multicolumn{2}{|r|}{3 regimes } & 593.1 & $1.0 \%$ \\
\hline \multicolumn{4}{|l|}{ MSW } \\
\hline \multicolumn{4}{|c|}{2 regimes } \\
\hline & $p=1$ & 288.8 & $51.8 \%$ \\
\hline & $p=2$ & 284.4 & $52.5 \%$ \\
\hline & $p=3$ & 331.9 & $44.6 \%$ \\
\hline & $p=4$ & 329.1 & $45.1 \%$ \\
\hline & $p=5$ & 329.6 & $45.0 \%$ \\
\hline \multicolumn{4}{|c|}{3 regimes } \\
\hline & $p=1$ & 191.8 & $68.0 \%$ \\
\hline & $p=2$ & 176.0 & $70.6 \%$ \\
\hline & $p=3$ & 237.6 & $60.4 \%$ \\
\hline & $p=4$ & 194.4 & $67.6 \%$ \\
\hline & $p=5$ & 233.9 & $61.0 \%$ \\
\hline
\end{tabular}

$\mathrm{T}$ a b 1 e 2. Particular components of the time series analysis. Relative improvement comparing to AR(1) model is calculated as $\left.\left(\mathrm{RSS}_{\mathrm{AR}(1)}-\mathrm{RSS}\right) / \mathrm{RSS}_{\mathrm{AR}(1)}\right)$.

\begin{tabular}{|c|c|c|c|}
\hline \multicolumn{2}{|c|}{ Component } & RSS & Relative improvement comparing to AR(1) [\%] \\
\hline \multicolumn{2}{|c|}{ Original data } & - & - \\
\hline \multicolumn{4}{|c|}{ Systematic components } \\
\hline & Trend & 8372.5 & - \\
\hline & Seasonal & 3351.2 & - \\
\hline & Cyclical & 3060.8 & - \\
\hline \multicolumn{4}{|c|}{ ARMA class } \\
\hline & $\mathrm{AR}(1)$ & 2068.1 & $0.0 \%$ \\
\hline & $\operatorname{AR}(2)$ & 1908.3 & $7.7 \%$ \\
\hline & $\operatorname{AR}(3)$ & 2061.6 & $0.3 \%$ \\
\hline & $\operatorname{ARMA}(1,1)$ & 2072.8 & $-0.2 \%$ \\
\hline & $\mathrm{AR}(4)$ & 2060.7 & $0.4 \%$ \\
\hline & $\operatorname{ARMA}(2,1)$ & 2091.3 & $-1.1 \%$ \\
\hline & $\operatorname{ARMA}(1,3)$ & 2549.8 & $-23.3 \%$ \\
\hline \multicolumn{4}{|l|}{ SETAR } \\
\hline & \multirow{2}{*}{$\begin{array}{l}2 \text { regimes } \\
3 \text { regimes }\end{array}$} & 2038.12 & $1.4 \%$ \\
\hline & & 1057.8 & $48.9 \%$ \\
\hline \multicolumn{4}{|l|}{ MSW } \\
\hline & \multicolumn{3}{|l|}{2 regimes } \\
\hline & $p=1$ & 1059.3 & $48.8 \%$ \\
\hline & $p=2$ & 1069.9 & $48.3 \%$ \\
\hline & $p=3$ & 1083.2 & $47.6 \%$ \\
\hline & $p=4$ & 1081.5 & $47.7 \%$ \\
\hline & $p=5$ & 1051.7 & $49.1 \%$ \\
\hline \multicolumn{4}{|c|}{3 regimes } \\
\hline & $p=1$ & 772.1 & $62.7 \%$ \\
\hline & $p=2$ & 659.6 & $68.1 \%$ \\
\hline & $p=3$ & 592.3 & $71.4 \%$ \\
\hline & $p=4$ & 591.1 & $71.4 \%$ \\
\hline & $p=5$ & 517.1 & $75.0 \%$ \\
\hline
\end{tabular}


a)

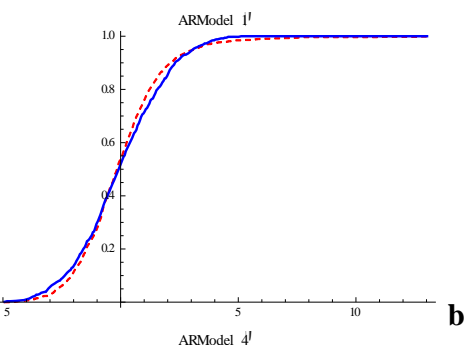

d)
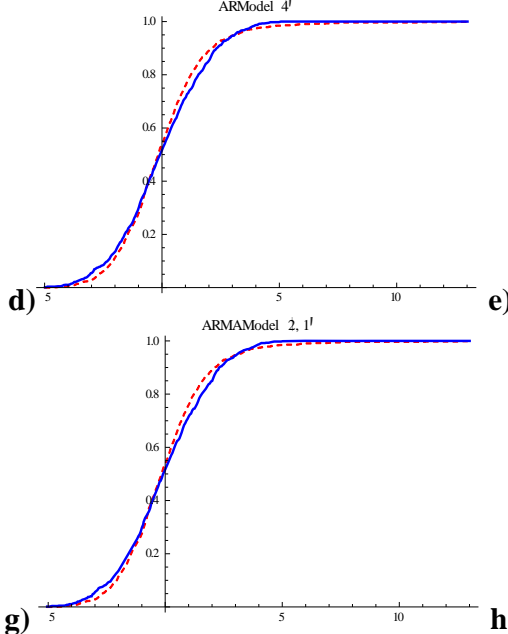

b)
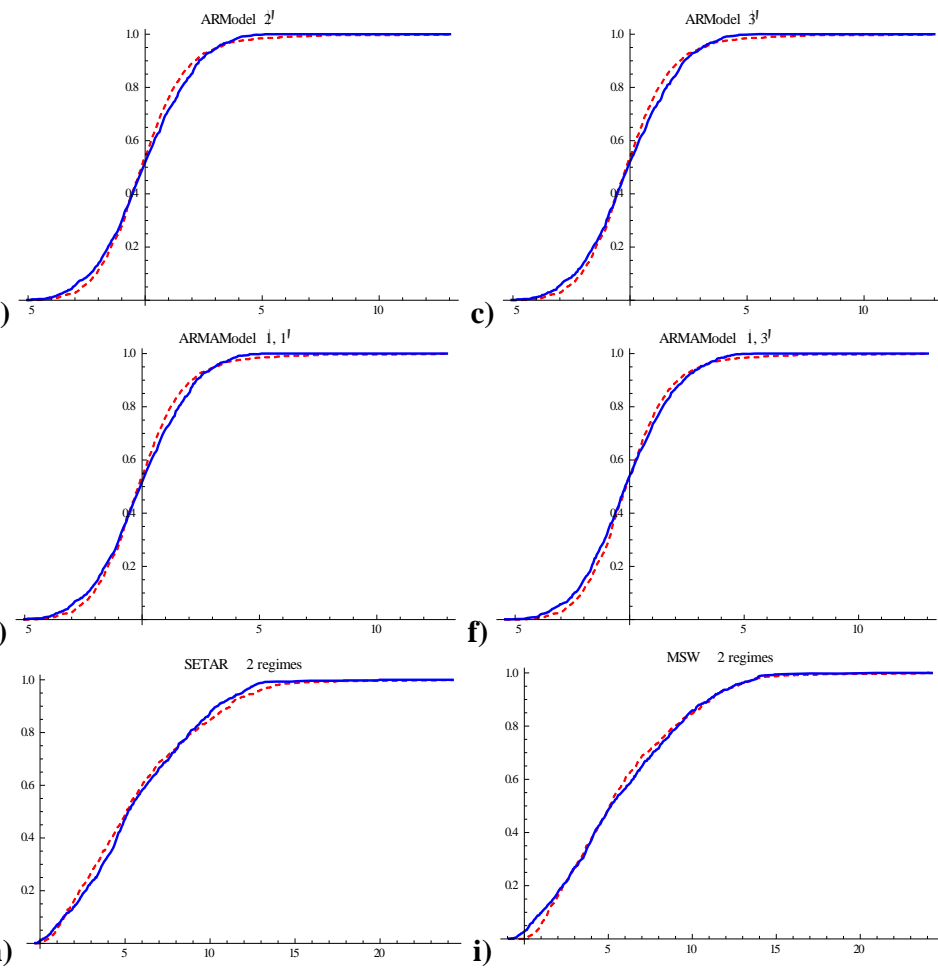

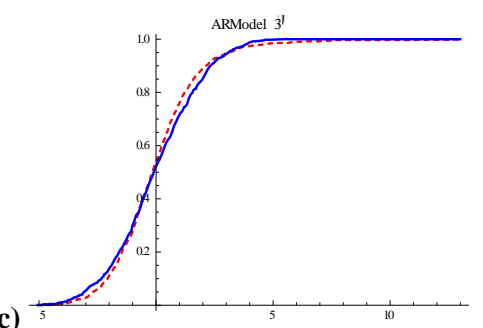

MSW 2 regimes

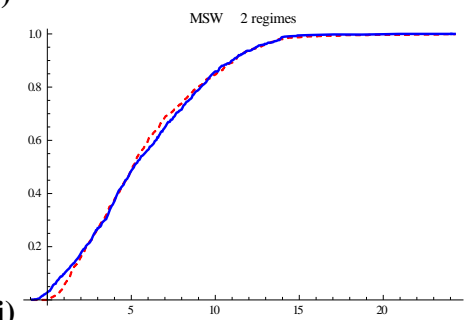

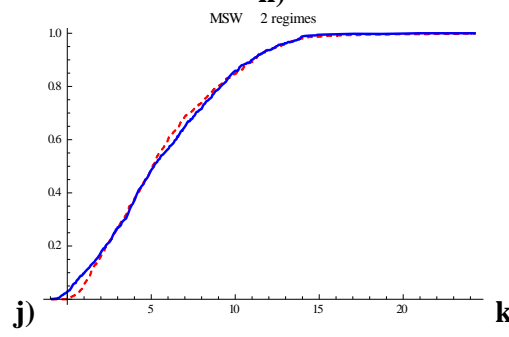

k)

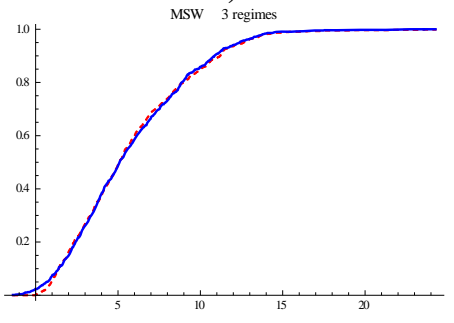

Fig. 8. Empirical cumulative distribution functions calculated for selected models of the River Stour time series. Red dashed line represents CDF function for modelled data and blue line for model. The particular plots represent following models: a) AR(1), b) $\operatorname{AR}(2)$, c) $\operatorname{AR}(3)$, d) $\operatorname{AR}(4)$, e) $\operatorname{ARMA}(1,1)$, f) $\operatorname{ARMA}(1,3)$, g) $\operatorname{ARMA}(2,1)$, h) SETAR - 2 regimes, i) SETAR - 3 regimes, j) MSW -2 regimes and $\mathrm{k}$ ) MSW -3 regimes.

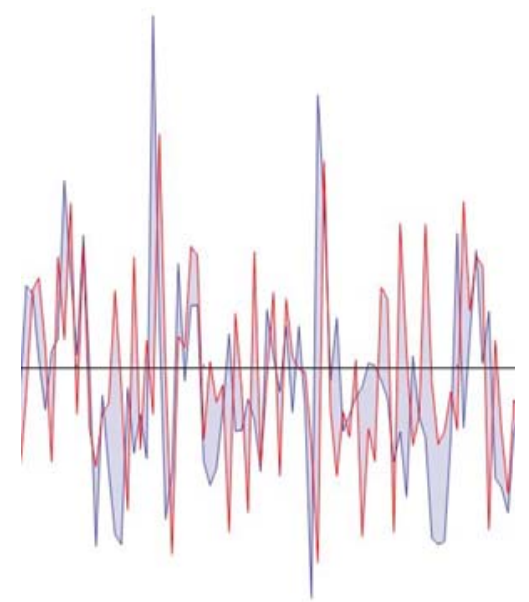

Fig. 9. Detail of an ARMA model demonstrating that the simulated values are shifted by 1 or more time steps towards the original data. This causes that despite a good visual fit the RSS of a particular model can be worse than in the case of other models. 
are MSW2(2) and MSW3(2) with a relative improvement against simple AR(1) model of $52.5 \%$ and $70.6 \%$ respectively (see Tab. 1 ). In the case of River Stour the best two and three-regime models are MSW2(5) and MSW3(5) with a relative improvement against simple AR(1) model of $49.1 \%$ and $75 \%$ respectively (see Tab. 2). The visual assessment of the models (Figs. 4 and 7) shows that in both datasets the MSW models fit the original time series much better than SETAR and most of the ARMA class models (except of ARMA $(1,1)$ for Ouse and ARMA $(2,1)$ and $\operatorname{ARMA}(1,3)$ for Stour which on the other hand have much higher values of RSS). When comparing two and threeregime MSW models all three-regime models give lower values of RSS with better description of extreme values. The explanation of the better performance of the MSW models comparing to SETAR models wasn't the primary objective of this study. Since it would require additional study of the models structures it is a motivation for further research.

The comparison of models of class ARMA and models with multiple regimes represented by SETAR and MSW models showed that both nonlinear groups of models gave better fits with lower values of RSS (Tabs. 1 and 2). The visual assessment of models plotted against original time series showed that especially in the case of models of class ARMA, models that could describe all extreme values were those with the highest values of RSS. This problem could be solved by a change in the fitness function, where the models could be fitted on extreme values.

\section{Conclusion}

While in the previous studies dealing with time series analysis of nitrate concentrations the residuals after removing trend and seasonal component were modelled by simple linear models of class ARMA in this study more advanced nonlinear models with multiple regimes represented by SETAR and MSW models have been used. In addition the cyclical component, removing the residual periodicity, has been included into the model of systematic components.

In both datasets the best curve describing the trend component was Gompertz curve highlighting the period between 1960 and 1970 when the rapid rise in nitrate-nitrogen concentrations occurred. This rapid change has also been observed in other catchments and is assigned to expansion and inten- sification of agriculture. By adding the cyclical component into the model of systematic components even the residual periodicity left after removing the seasonal component has been removed. Modelling the residuals showed that by applying the nonlinear SETAR and MSW models lower values of RSS could be achieved than by simple models of class ARMA. This is especially true for MSW models that improved the fit of simple AR(1) models by $50 \%$ to $75 \%$ in average. In the case of SETAR models the relative improvement against AR(1) models was only around $1 \%$ to $4 \%$ with an exception of three-regime SETAR model of River Stour where the relative improvement was $48.9 \%$. However, the visual assessment of all models plotted against the original time series showed that despite a high value of $\operatorname{RSS}$, models $\operatorname{ARMA}(1,1)$ for River Ouse and $\operatorname{ARMA}(2,1)$ and $\operatorname{ARMA}(1,3)$ for River Stour could describe the time series much better than other models of class ARMA and SETAR with lower values of RSS. In comparison MSW models especially those with three regimes gave very good visual fit catching most of the extreme values. This problem could be fixed by changing the fitness function or by fitting models on extreme values.

To answer the main question of this study - can nonlinear models can improve the model performance in comparison to linear models of class ARMA as in the case of many studies in econometrics? The answer would be yes. Especially MSW models can describe analysed time series much better than traditional models of class ARMA in a reasonable amount of time.

Acknowledgement. The research presented in the paper was supported by the Slovak Research and Development Agency under the contract No. APVV-0496-10 and by the VEGA Scientific Grant Agency grant No. 1/0908/11. The supports are gratefully acknowledged. We greatly appreciate the recommendations of the two anonymous reviewers for improvements to the manuscript.

\section{REFERENCES}

AMENDOLA A., 2003: Forecasting performance of regime switching models in hydrological time series. Giornata di Studio: Metodi Statistici e Matematici per le Analisi Idrologiche- Roma, CNR-GNDCI.

BETTON, C., WEB, B.W., WALLING, D.E., 1991: Recent trends in NO3-N concentration and loads in British rivers. IAHS, 203, p. 169-180.

BOX, G.E.P. and JENKINS G.M., 1970: Time Series Analysis: Forecasting and Control. Holden-Day, San Francisco. 
BOX G.E.P., JENKINS G.M., 1976: Time series analysis: forecasting and control. Holden-Day, Oakland, California.

BROOKS C., 2009: RATS Handbook to Accompany Introductory Econometrics for Finance. Cambridge University Press, Cambridge.

BURT T.P. and ARKELL B.P., 1987: Temporal and spatial patterns of nitrate losses from agricultural catchment. Soil Use and Management, Vol. 3, p. 138-143.

BURT T.P., WORRALL F., 2009: Stream nitrate levels in a small catchment in south west England over a period of 35 years (1970-2005). Hydrological Processes, Vol. 23, p. 2056-2068.

CASEY H. and CLARKE R.T., 1979: Statistical analysis of nitrate concentrations from the River Frome (Dorset) for period 1965-76. Freshwater Biology, Vol. 9, p. 91-97.

FIRAT M. and GUNGOR M., 2010: Monthly total sediment forecasting using adaptive neuro fuzzy inference system. Stoch. Environ. Res. Risk Assess., Vol. 24, No. 2, p. 259_ -270 .

FRANSES P.H. and VAN DIJK D., 2003: Nonlinear Time Series Models in Empirical Finance. Cambridge University Press, Cambridge.

CHATFIELD C., 1989: The Analysis of Time Series: An Introduction. ( $4^{\text {th }}$ ed), Chapman and Hall, London.

CHATFIELD C., 2001: Prediction intervals, in Principles of Forecasting: A Handbook for Researchers and Practitioners. Edited by J. Armstrong, Springer, New York.

EC (European Commission), 1991: Directive 91/676/EEC of the European Parliament and of the Council of 12 December 1991 concerning the protection of water against pollution caused by nitrates from agricultural sources. Office for Official Publications of the European Communities, Luxembourg.

EC (European Commission), 1991: Directive 91/271/EEC of the European Parliament and the Council of 21 May 1991 concerning urban waste water treatment. Office for Official Publications of the European Communities, Luxembourg.

EC (European Commission), 2000: Directive 2000/60/EC of the European Parliament and of the Council of 23 October 2000 establishing a framework for Community action in the field of water policy. Office for Official Publications of the European Communities, Luxembourg.

EEA (European Environment Agency), 2005: Source apportionment of nitrogen and phosphorus inputs into the aquatic environment. EEA, Copenhagen.

FISHER R.A., 1929: Tests of significance in harmonic analysis. Proceedings of the Royal Society of London, Series A, Vol. 125, No. 796, p. 54-59.

HAMILTON J.D., 1989: A New Approach to the Economic Analysis of Nonstationary Time-series and the Business Cycle. Econometrica, Vol. 57, No. 2, p. 357-384.

HAMILTON J.D., 1994: Time Series Analysis. Princeton University Press, Princeton, New Jersey.

HANNAN E.J. and RISSANEN J., 1982: Recursive estimation of mixed autoregressive moving average order. Biometrica, Vol. 69, p. 81-94. Correction (1983), 70, 303.

HOWDEN N.J.K., BOWES, M.J., CLARK, A.D.J., HUMPRIES, N. and NEAL, C., 2009: Water quality, nutrients and the European union's Water Framework Directive in a lowland agricultural region: Suffolk, south-east England. Science of the Total Environment, Vol. 407, 8, p. 2966$-2979$.

HOWDEN N.J.K. and BURT T.P., 2008: Temporal and spatial analysis of nitrate concentrations from the Frome and Piddle catchments in Dorset (UK) for water years 1978 to 2007: Evidence for nitrate breakthrough? Science of the Total Environment, Vol. 407, 1, p. 507-526.

JENKINS G.M., 1968: Spectral analysis and its applications. Holden-Day, Oakland, California.

KWIATKOWSKI D., PHILLIPS P.C.B., SCHMIDT P. and SHIN Y., 1992: Testing the null hypothesis of stationarity against the alternative of a unit root. J. Econometrics, Vol. 54 , p. $159-178$.

LENCUCHOVA J., 2009: MSW models of time-series. (In Slovak.) (MSW modely časových radov.) [Unpublished Masters thesis.] Slovak University of Technology, Bratislava.

PEKAROVA P., MIKLANEK P. and RONCAK P., 1995: Stream Load and Specific yield of nitrogen and phosphates from Slovakia. J. Hydrol. Hydromech., Vol. 43, No. 4-5, p. 233-248.

PEKAROVA P. and ONDERKA M., 2005: Modelling nitrate concentrations in Vydrica River. (Modelovanie koncentrácií dusičnanov v toku Vydrica.) Acta Hydrologica Slovaka, 6, 1, p. 141-148.

PEKAROVA P. and PEKAR J., 1996: The Impact of Land Use on Stream Water Quality in Slovakia. J. Hydrology, Vol. 180, No. 1-4, p. 333-350.

PEKAROVA P., ONDERKA M., PEKAR J., RONCAK P. and MIKLANEK P., 2009: Prediction of water quality in the Danube River under extreme hydrological and temperature conditions. J. Hydrol. Hydromech., Vol. 57, No. 1, p. 3-15.

SCHOCH A.L., SCHILLING K.E. and CHAN K.S., 2009: Time-series modeling of reservoir effects on river nitrate concentrations. Advances in Water Resources, Vol. 32, p. 1197-1205.

SEEHAUSEN O., VAN ALPEN J.J.M. and WITTE F., 1997: Cichlid fish diversity threatened by eutrophication that curbs sexual selection. Science, Vol. 277, No. 5333, p. 1808-1811.

STRONGE K.M., LENNOX S.D. and SMITH R.V., 1997: Predicting nitrate concentrations in Northern Ireland rivers using time series analysis. J. Environmental Quality, Vol. 26, No. 6, p. 1599-1604.

YURDUSEV M.A. and FIRAT M., 2009: Adaptive neuro fuzzy interface system approach for municipal water consumption modelling: An application to Izmir, Turkey. J. Hydrology, Vol. 365, No. 3-4, p. 225-234.

WORRALL F., SWANK W.T. and BURT T.P., 2003: Changes in stream nitrate concentrations due to land management practices, ecological succession and climate: Developing a systems approach to integrated catchment response. Water Resources Research, Vol. 39, No. 7, p. 1177.

WORRALL F. and BURT T.P., 1998: Decomposition of river water nitrate time-series - comparing agricultural and urban signals. The Science of the Total Environment, Vol. 210 211 , p. 153-162.

WORRALL F. and BURT T.P., 1999: A univariate model of river water nitrate time series. Journal of Hydrology, Vol. 214, No. 1-4, p. 74-90.

WRc (consultant), 2004: Updating an estimate if the source apportionment of nitrogen to waters in England and Wales (report to DEFRA), DEFRA Reference No.: RSE-12.

Received 25 October 2010 Accepted 12. April 2011 